\title{
PENYULUHAN PEMAHAMAN TOPONIMI SEBAGAI SUMBER PENGUATAN BUDAYA DALAM UPAYA PENINGKATAN POTENSI PARIWISATA DI KECAMATAN CIBALONG, KABUPATEN GARUT
}

\author{
Cece Sobarna, Gugun Gunardi, Asri Soraya Afsari \\ Program Studi Sastra Sunda, Fakultas Ilmu Budaya, Universitas Padjadjaran \\ E-mail: asri.s.afsari@unpad.ac.id
}

\begin{abstract}
ABSTRAK. Artikel ini merupakan hasil kegiatan pengabdian kepada masyarakat yang dilakukan oleh tim pelaksana bersama mahasiswa, dan masyarakat sasaran. Tujuan pengabdian kepada masyarakat ini untuk mencari solusi dalam upaya peningkatan potensi pariwisata melalui penelusuran toponimi. Kegiatan dilakukan melalui metode penyuluhan dan pelatihan menulis folklor di media sosial. Manfaat penyuluhan ini dapat memperkuat nilai-nilai budaya yang terkandung pada cerita asal-usul nama tempat di Kecamatan Cibalong. Pemilihan lokasi kegiatan pengabdian kepada masyarakat ini berdasarkan pertimbangan bahwa Kecamatan Cibalong merupakan wilayah yang mengandung banyak potensi wisata budaya dan wisata pantai, seperti pantai Karang Paranje, Pantai Cijeruk Indah dan Pantai Cibako. Penamaan lokasi-lokasi tersebut tentu didasari oleh cerita rakyat yang melatarbelakanginya. Cerita rakyat tersebut pun sampai saat ini masih dipercaya oleh masyarakat. Namun demikian, unsur aparat desa dan pemuda penggerak budaya, pariwisata, dan pendidikan setempat belum mengoptimalkan pentingnya toponimi sebagai sumber penguatan budaya dalam upaya peningkatan potensi pariwisata. Tahapan kegiatan yang telah dilaksanakan adalah survey lokasi, pengurusan perizinan, penyusunan materi penyuluhan, pelaksanaan penyuluhan pemahaman toponimi, pelatihan menulis deskripsi asal-usul nama tempat (toponimi) di media sosial, dan evaluasi untuk mengukur tingkat keberhasilan kegiatan ini. Melalui kegiatan ini diharapkan pengetahuan budaya dan keterampilan menulis folklor masyarakat sasaran dapat meningkat sehingga dapat mendukung pada peningkatan potensi pariwisata.
\end{abstract}

Kata kunci: toponimi; Cibalong; penyuluha; pelatihan; folklor

\begin{abstract}
This article is the result of community service activities carried out by the implementation team with students, and the target community. The purpose is to find solutions in efforts to increase tourism potential through toponymy research. The activity is carried out through counseling methods and folklore writing training on social media. The benefits can strengthen the cultural values contained in the story of the origin of name place in the District Cibalong. The selection of locations is based on the consideration that Cibalong Subdistrict is an area that contains a lot of potential cultural tourism and beach tourism, such as Karang Paranje beach, Cijeruk Indah Beach, and Cibako Beach. The naming of these locations is certainly based on the folklore that lies behind them. Even this folklore is still believed by the society. However, elements of the village apparatus and youth activists of culture, tourism, and local education have not optimized the importance of toponymy as a source of cultural reinforcement in effort to increase tourism potential. Stages of activities that have been carried out are location survey, licensing management, preparation of counseling material, implementation of counseling on understanding toponymy, training in writing folklore on social media, and evaluation to measure the success rate of this activity. Through this activity it is hoped that the cultural knowledge and description writing skills of the target community can be increased so that it can support the increased tourism potential.
\end{abstract}

Key words: toponymy; Cibalong; counseling; training; folklore

\section{PENDAHULUAN}

Cibalong merupakan satu dari empat puluh dua kecamatan yang ada di wilayah Garut bagian selatan. Kecamatan Cibalong secara administratif memiliki dua belasdesa, yakniMekarsari,Karyasari,Karyamukti,Sagara, Maroko, Sancang, Simpang, Cigaronggong, Mekarmukti, Mekarwangi, dan Najaten. Wilayah Kecamatan Cibalong berbatasan dengan Samudera Indonesia di sebelah selatan, berbatasan dengan Kecamatan Pameungpeuk di sebelah barat, berbatasan dengan Kecamatan Cisompet di sebelah utara, dan berbatasan dengan Kabupaten Tasikmalaya di sebelah timur. Secara topografis, lahan tanah di Kecamatan Cibalong tergolong bervariatif. Lahan seluas 25\% atau sekitar 6.014,5 Ha merupakan tanah datar dan sisanya seluas $75 \%$ atau sekitar 18.042 Ha merupakan tanah curam atau berbukit (sumber: Laporan Bulanan Kegiatan Pemerintahan, Pelaksanaan Pembangunan dan Pelayanan/ Pembinaan Kemasyarakatan di Kecamatan Cibalong).
Kecamatan Cibalong merupakan wilayah yang mengandung banyak potensi wisata budaya terutama wisata budaya spiritual dan wisata pantai. Potensi wisata ini tersebar di Desa Sancang, Sagara, Karyamukti, dan Karyasari, Kecamatan Cibalong, Kabupaten Garut. Setidaknya di sana terdapat 20 tempat wisata spiritual, di antaranya "Kajayaan" di Blok Cipangisikan, Ciporeang, Cibako, dan Blok Cijeruk. Sobarna (2019: 168) menjelaskan bahwa nama tempat terkait erat pula dengan foklor mengingat dalam nama tempat terkandung cerita atau sejarah yang secara tradisi diturunkan turun-temurun. Bentuk cerita tersebut, biasanya legenda, mengungkapkan penamaan tempat, seperti jalan dan tempat. Penamaan tempat itu tentu didasari pula oleh cerita rakyat yang melatarbelakanginya. Artinya, terdapat aspek integrasi antara bahasa dengan budaya (periksa Indira, 2018: 239). Bahasa yang dimaksud dalam hal ini adalah penamaan tempat atau toponimi.

Secara harfiah toponimi berarti nama tempat. Dalam teori linguistik, toponimi dapat dilihat sebagai 
'tanda'yang terjaditidak secara arbitrer. Radding \& Western (2010: 399) mengemukakan bahwa konteks di antara kata-kata yang arbitrer di dalam suatu bahasa tertentu dan dalam situasi tertentu tidaklah artbitrer. Kita mencintai dan memedulikan suatu nama tertentu karena nama tersebut mengandung lapisan makna. Lapisan tersebut berasal dari budaya tempat itu berada dan melampaui kata-kata seharihari atau biasa. Dengan demikian, toponimi harus dapat dipahami sebagai sebentuk 'tanda'.

Dalam hal ini, suatu nama tempat merupakan suatu tanda yang mengacu kepada suatu cerita (story) dan juga sejarah (history) yang berakar dalam pada budaya lokal. Perubahan dalam suatu budaya akan mengakibatkan perubahan pemaknaan terhadap nama tempat itu sebagai tanda (Radding \& Western, 2010). Lebih lanjut Salve (2016) mengemukakan bahwa melalui toponimi, kita dapat mengungkap nilai-nilai budaya dari nenek moyang serta rahasia dan mitos yang berkembang dalam sebuah masyarakat dibalik toponiminya. Oleh sebab itu, pemaknaan suatu nama dapat ditelusuri melalui cerita yang menyertainya. Terutama melalui cerita atau tradisi lisan yang menurunkan cerita nama tempat tersebut.

Cerita rakyat atau folklor yang mendasari nama tempat di Kecamatan Cibalong sampai saat ini masih dipercaya oleh masyarakat. Namun demikian, permasalahan yang muncul di masyarakat Kecamatan Cibalong adalah para pemuda penggerak budaya, pariwisata, dan pendidikan serta aparat desa setempat belum mengoptimalkan pentingnya toponimi sebagai sumber penguatan budaya dan peningkatan potensi pariwisata.

Objek pariwisata lainnya, berupa pariwisata pantai yang berada di Kecamatan Cibalong, di antaranya terdapat di Desa Karyasari, Desa Sagara, dan Desa Sancang. Lokasi objek wisata pantai Karang Paranje berada di Desa Karyasari, Pantai Cijeruk Indah berada di Desa Sagara, dan Pantai Cibako berada di Desa Sancang. Ketiga pantai ini masing-masing memiliki keindahan. Namun, kenyataan yang tampak di masyarakat adalah dari segi pengelolaannya masih belum maksimal. Hal ini menjadi sebuah permasalahan juga, padahal potensi wisata untuk menarik minat para pengunjung yang dimiliki baik pantai Karang Paranje, Cijeruk, maupun Cibako cukup besar. Wiseza (2017) menyatakan bahwa banyak faktor yang dapat diperlukan dalam mendukung usaha pengembangan sebuah pariwisata. Faktor-faktor tersebut di antaranya: pihak pengelola dan sikap masyarakat. faktor alam yang mendukung pengembangan pariwisata lokasi, topografi, iklim dan air. Di samping itu, keberhasilan pengembangan obyek wisata suatu daerah harus ditunjang pula oleh terjalinnya kerja sama yang baik antarunsur-unsur kepariwisataan (pemerintah, swasta, pengelola) dan partisipasi masyarakat di daerah tujuan wisata. Kasus yang terjadi di Kecamatan Cibalong adalah masih minimnya kesadaran para pengelola dan masyarakat setempat terhadap pengetahuan budaya local termasuk pemahaman terhadap toponimi.
Sejalan dengan Wiseza (2017), Setiawan (2016) juga mengemukakan bahwa keberadaan SDM disinyalir berperanan penting pula dalam pengembangan pariwisata. SDM pariwisata mencakup wisatawan/pelaku wisata (tourist) atau sebagai pekerja (employment). Peran SDM sebagai pekerja dapat berupa SDM di lembaga pemerintah, SDM yang bertindak sebagai pengusaha (wirausaha) yang berperan dalam menentukan kepuasan dan kualitas para pekerja, para pakar dan profesional yang turut berperan dalam mengamati, mengendalikan, dan meningkatkan kualitas kepariwisataan serta yang tidak kalah pentingnya masyarakat di sekitar kawasan wisata yang bukan termasuk ke dalam kategori di atas, tetapi turut menentukan kenyamanan, kepuasan para wisatawan yang berkunjung ke kawasan tersebut.

Lebih jauh Setiawan (2016) menjelaskan bahwa di banyak negara, dalam proses perencanaan dan pengembangan kepariwisataan, pembahasan tentang SDM yang dibutuhkan dalam pelayanan kegiatan kepariwisataan yang benar dan efektif seringkali mendapat perhatian yang rendah. Dalam beberapa kasus, bahkan sama sekali diabaikan. Hal tersebut mengakibatkan timbulnya permasalahan serius dalam industri kepariwisataan, dan memungkinkan terhalangnya partisipasi masyarakat setempat dalam kegiatan ekonomi yang dikembangkan dari pengembangan kepariwisataan. Hal yang sama terjadi pula pada keberadaan pariwisata di Kabupaten Garut, terutama Kecamatan Cibalong. Bukan hanya permasalahan SDM yang mengemuka terkait dengan pemuda penggerak budaya, pariwisata, dan pendidikan di Kecamatan Cibalong tetapi juga pihak aparat desa yang belum mampu mengoptimalkan beragam potensi budaya setempat. Masih banyak data budaya yang belum didokumentasikan dan diinventarsasi dengan baik. Unsur aparat desa dan pemuda penggerak budaya, pariwisata, dan pendidikan perlu dibekali pemahaman budaya, termasuk salah satunya toponimi mengingat kehadiran pariwisata di suatu tempat dapat mengubah tatanan kehidupan masyarakat lokal. Seperti yang dijelaskan oleh Agustiningrum (2018: 140) bahwa pariwisata dengan segala aspek kehidupan yang terkait di dalamnya akan menuntut konsekuensi dari terjadinya pertemuan dua budaya atau lebih yang berbeda, yaitu budaya para wisatawan dengan budaya masyarakat sekitar obyek wisata. Budaya-budaya yang berbeda dan saling bersentuhan itu akan membawa pengaruh yang menimbulkan dampak terhadap segala aspek kehidupan dalam masyarakat sekitar obyek wisata. Oleh sebab itu, dengan adanya kesadaran dan pemahaman budaya, diharapkan unsur aparat desa dan pemuda penggerak budaya, pariwisata, serta masyarakat lokal tidak mudah terpengaruh dan terbawa oleh budaya luar.

Lokasi kegiatan pengabdian ini dipusatkan di Kecamatan Cibalong, Kabupaten Garut. Secara topografi, kawasan ini merupakan kombinasi dataran landau dan perbukitan. Program pengabdian kepada masyarakat 
ini diharapkan dapat membantu masyarakat sasaran, yakni unsur aparat desa dan pemuda penggerak budaya, pariwisata, dan pendidikan dalam memahami pentingnya toponimi sebagai sumber penguatan budaya dalam upaya peningkatan potensi pariwisata. Dengan demikian, kegiatan pengabdian ini diharapkan dapat menjadi sebuah upaya untuk memelihara kekayaan khazanah budaya lokal (melalui toponimi) yang ada di Kecamatan Cibalong, Kabupaten Garut sekaligus meningkatkan potensi-potensi wisata yang ada di sana.

Berdasarkan paparan di atas, permasalahan yang dapat dirumuskan berdasarkan kenyataan di lapangan adalah sebagai berikut: (1). Kecamatan Cibalong, Kabupaten Garut menyimpan beragam potensi budaya, salah satunya toponimi. Namun demikian, beragam potensi budaya tersebut belum tergali secara optimal termasuk toponimi, (2). Unsur aparat desa dan pemuda penggerak budaya, pariwisata, dan pendidikan Kabupaten Cibalong masih banyak yang belum memahami pentingnya toponimi sebagai sumber penguatan budaya dalam upaya peningkatan potensi pariwisata.

Tujuan kegiatan pengabdian kepada masyarakat dapat dirumuskan sebagai berikut: (1). Menumbuhkan kesadaran unsur aparat desa dan pemuda penggerak budaya, pariwisata, dan pendidikan Kecamatan Cibalong agar mereka memiliki kesadaran yang tinggi akan pentingnya pemahaman toponimi, (2). Menumbuhkan semangat kepada unsur aparat desa dan pemuda penggerak budaya, pariwisata, dan pendidikan Kecamatan Cibalong untuk menggali toponimi sebagai bagian dari budaya lokal yang dapat mendukung pada peningkatan potensi wisata, dan (3). Terjalin kerja sama antara masyarakat akademis dan masyarakat umum melalui kegiatan pengabdian kepada masyarakat.

\section{METODE}

Dalam kegiatan pengabdian kepada masyarakat ini dilakukan beberapa tahapan kegiatan yang tidak lepas dari masyarakat sasaran sebagai indikator keberhasilan. Adapun tahapan-tahapan yang dilakukan sebagai berikut.

(1) Persiapan kegiatan, dalam tahap ini tim pelaksana mempersiapkan berbagai hal untuk pelaksanaan program PPM, seperti survey awal, rapat koordinasi dan penyusunan program kegiatan.

Tim pelaksana dibantu oleh tenaga lapangan, yakni sembilan mahasiswa KKNM. Tenaga lapangan membantu tim dalam persiapan pelaksanaan kegiatan, yaitu dilibatkan dalam survei awal ke Kecamatan Cibalong, Kabupaten Garut

(2) Penyediaan tempat, dalam tahap ini tim pelaksana kegiatan dibantu tenaga lapangan berkoordinasi dengan masyarakat sasaran dan memeriksa kelayakan tempat yang akan digunakan untuk penyuluhan. Aula Kecamatan Cibalong dipilih sebagai tempat berlangsungnya kegiatan penyuluhan karena lokasinya strategis.
(3). Penyusunan materi, Materi kegiatan yang disampaikan dalam kegiatan pengabdian meliputi aspek-aspek yang berkaitan dengan topinimi, folklor, teknik menulis deskripsi asal-usul nama tempat (toponimi) di media sosial yang berkaitan dengan upaya peningkatan potensi wisata.

(4) Pelaksanaan kegiatan dan evaluasi, pelaksanaan kegiatan pengabdian ini dilakukan melalui kegiatan tatap muka selama dua bulan. Dalam kurun waktu dua bulan tersebut, dilakukan penyuluhan budaya (Pemahaman Toponimi) dan praktik langsung pelatihan menulis asal-usul nama tempat (toponimi) di media sosial untuk meningkatkan potensi pariwisata Kecamatan Cibalong. Evaluasi program kegiatan dilakukan setelah pelatihan menulis asal-usul nama tempat (toponimi) selesai dilakukan. Evaluasi dilakukan sebagai indikator keberhasilan kegiatan.

\section{HASIL DAN PEMBAHASAN}

Khalayak sasaran yang dianggap strategis dan tepat untuk dilibatkan dalam penerapan Pengabdian kepada Masyarakat melalui kegiatan Penyuluhan "Toponimi Sebagai Sumber Penguatan Budaya di Kecamatan Cibalong, Kabupaten Garut dalam Upaya Peningkatan Potensi Pariwisata" adalah unsur aparat desa dan pemuda penggerak budaya, pariwisata, dan pendidikan sebanyak 25 orang. Khalayak sasaran yang mengikuti acara penyuluhan pada akhirnya diharapkan dapat memperoleh pemahaman budaya terutama toponimi yang selama ini berlum tersentuh sehingga pengetahuan budaya mereka bertambah dan mereka mampu mengembangkan berbagai potensi budaya dan pariwisata yang ada di Kecamatan Cibalong, Kabupaten Garut secara optimal.

Materi kegiatan yang disampaikan dalam kegiatan penyuluhan meliputi aspek-aspek yang berkaitan dengan topinimi, folklor, teknik menulis toponimi di media sosial. Kegiatan penyuluhan diawali dengan pemaparan materi penyuluhan oleh tim pelaksana. Materi penyuluhan yang diberikan kepada para peserta adalah pemahaman mengenai toponimi dan folklor, hubungan toponimi dan folklor, serta toponimi sebagai sumber penguatan budaya untuk peningkatan potensi pariwisata setempat. Pemaparan materi dilengkapi dengan tayangan slide ppt hal ini bertujuan agar masyarakat sasaran tertarik untuk menyimak dan dapat dengan mudah memahami materi yang disampaikan. Setelah sesi pemaparan materi selesai dilanjutkan dengan sesi diskusi. Pada sesi ini para peserta banyak yang mengemukakan pendapat. Pendapat yang disampaikan bernada positif. Para peserta merasa senang mendapat pengetahuan baru tentang toponimi dan budaya lokal, mereka juga baru memamhami bahwa cerita rakyat yang selama ini mereka ketahui ternyata dapat mendukung pada peningkatan potensi pariwisata setempat. Para peserta pun tampak begitu antusias dan bersemangat dalam mengikuti kegiatan penyuluhan ini. Hal tersebut 
dikarenakan selama ini masyarakat sasaran belum pernah mendapatkan penyuluhan dari segi budaya terlebih dalam upaya peningkatan potensi pariwisata. Secara umum kegiatan penyuluhan ini dapat dikatakan berjalan dengan sukses, baik, dan lancar. Meskipun di awal terdapat sedikit kendala dalam hal keterlembatan waktu pelaksaaan, tetapi kegiatan selanjutnya dapat berlangsung dengan baik. Para peserta pun mengharapkan agar kegiatan penyuluhan yang berkaitan dengan budaya tidak hanya sekali dilaksanakan. Dengan demikian, program kegiatan ini diharapkan dapat berlangsung secara berkesinambungan.

Kegiatan pada pertemuan berikutnya adalah pelatihan penulisan asal-usul nama tempat (toponimi) yang ada di Kecamatan Cibalong. Penulisan yang dimaksud adalah bentuk penulisan untuk di media sosial. Seperti kita ketahui bersama bahwa sosial media dewasa ini memegang andil yang besar dalam penyebaran berbagai informasi. Melalui sosial media segala bentuk informasi dapat tersebar dengan cepat dengan jangkauan yang luas.

Dengan demikian, melalui penulisan asal-usul nama tempat (toponimi) di media sosial (dalam hal ini instagram) diharapkan informasi terkait toponimi yang ada di Kecamatan Cibalong dapat tersebar dengan cepat dan luas. Tersebarnya informasi tersebut diharapkan dapat menunjang pada peningkatan potensi pariwisata dalam hal ini berupa pengenalan berbagai objek wisata yang ada di Kabupaten Garut bagian Selatan terutama Kecamatan Cibalong dan juga peningkatan jumlah wisatawan yang berkunjung ke sana.

Pada pelaksanaannya, sebelum kegiatan pelatihan penulisan dilakukan, tim pelaksana terlebih dahulu membekali para peserta dengan materi singkat terkait teknis penggalian toponimi di Kecamatan Cibalong, Kabupaten Garut yang mencakup pendokumentasian, pengkajian, pengembangan, dan pelindungan serta teknik menulis deskripsi asal-usul nama tempat (toponimi) di media sosial: perbedaan menulis di media massa dan media sosial: (1). media sosial (fungsi dan peran), (2). pengaruh dan manfaat media sosial, (3). media sosial sebagai sarana penyebaran informasi, dan (4) teknik menulis melukiskan asal-usul nama tempat (toponimi) melalui media sosial. Dalam kesempatan ini tim pelaksana dibantu oleh mahasiswa KKNM. Setelah sesi pemaparan materi selesai disampaikan berikutnya dilakukan sesi diskusi. Pada sesi ini para peserta tampak begitu bersemangat untuk bertanya dan mengemukakan pendapat. Beberapa peserta mengajukan pula sejumlah pertanyaan terkait kiat menulis deskripsi asal-usul nama tempat (toponimi) di media sosial bahkan ada peserta yang dengan sukarela tampil ke forum menceritakan asalusul nama Cibalong yang ia ketahui. Dia menyebutkan bahwa selama ini tradisi menceritakan asal-usul nama tempat di daerahnya sudah mulai jarang dilakukan. Melalui penyuluhan ini ia berharap para peserta juga masyarakat Cibalong dapat tergerak untuk kembali melestarikan tradisi tersebut.
Adapula peserta lain yang membagi pengalaman sebagai bagian dari pemuda penggerak budaya, pariwisata, dan pendidikan. Dia menyampaikan bahwa selama ini pengembangan potensi budaya di Kecamatan Cibalong memang masih minim karena belum terbangunnya sinergitas yang baik antara pihak baik aparat desa dan pemuda penggerak budaya, pariwisata, dan pendidikan. Sehubungan dengan hal ini, tim pelaksana memberikan saran agar setelah mengikuti kegiatan pengabdian ini ke depan kedua pihak tersebut diharapkan dapat duduk bersama merancang pengembangan potensi pariwisata di Cibalong.

Sesi berikutnya adalah pelatihan praktik menulis deskripsi asal-usul nama tempat (toponimi) untuk di media sosial. Sebagai tahap awal menulis, tim pelaksana memberikan kesempatan kepada peserta untuk menulis deskripsi asal-usul nama tempat (toponimi) pada selembar kertas. Mahasiswa KKNM ikut membantu tim pelaksana membagikan kertas dan bolpoin kepada peserta. Pelatihan penulisan ini bertujuan untuk mengukur sejauh mana para peserta mampu memahami materi yang telah disampaikan oleh tim pelaksana dan menuangkannya dalam bentuk deskripsi asal-usul nama tempat (toponimi) dengan menggunakan bahasa sastra (bahasa puitis). Tim pelaksana memberikan alokasi waktu selama 20 menit kepada para peserta untuk menulis deskripsi toponimi tersebut.

Setelah kegiatan praktik menulis selesai, hasil kerja para peserta kemudian dikumpulkan kembali kepada tim pelaksana. Pada tahap ini mahasiswa KKNM membantu pengumpulan kertas hasil kerja para peserta. Tim pelaksana selanjutnya memeriksa hasil tulisan para peserta sebagai bagian dari evaluasi hasil praktik. Dari 25 orang peserta yang terlibat, 20 peserta telah mampu menulis cerita asal-susul nama tempat (toponimi) yang ada di Cibalong dengan menggunakan bahasa sastra yang indah dan menulis secara ringkas tetapi informatif. Para peserta telah mampu menuliskan kalimat pembuka yang indah seperti perjalanan panjang menuju Garut bagian selatan ini luar biasa menakjubkan. kalimat ini merupakan pembuka deskripsi asal usul nama Cibalong yang ditulis oleh salah seorang peserta. Ada pula yang menuliskan kalimat pembuka dengan kalimat hembusan angin sepoi-sepoi mernerka tubuh ketika bermain pasir di Pantai Karang Paranje untuk melukiskan asal-usul nama Paranje dan kalimat tempat indah nan sejuk dengan hembusan angin laut untuk mendeskripsikan asal-usul nama Tambak Udang Mekarsari.

Lima peserta lainnya masuk ke dalam kategori penilaian cukup. Hal ini karena hasil tulisan mereka masih berupa tulisan umum (nonsastra) seperti kalimat pembuka Sakambangan merupakan suatu kampung yang berada di Desa Mekawangi untuk mendeskripsikan asal-usul nama Sakambangan. Ada pula yang menulis kalimat pembuka Karang Paranje merupakan salah satu pantai yang terletak di sebelah selatan Kab. Garut untuk mendeskripsikan asal-usul nama Karang Paranje. 
Hasil pelatihan ini dapat dikatakan berhasil sebab $80 \%$ peserta telah mampu menyerap informasi dan materi yang disampaikan oleh tim pelaksana dengan baik. Para peserta pun mampu membuktikan hal tersebut melalui hasil karya menulis deskripsi asalusul nama tempat (toponimi) dari praktik yang telah mereka ikuti. Di samping itu, terjadi pula perubahan sikap dari para peserta. Mereka memperoleh tambahan pengetahuan budaya terutama terkait toponimi dan cerita rakyat. Bekal ini dapat dimanfaatkan untuk menunjang peningkatan potensi pariwisata yang ada di Kecamatan Cibalong. Mereka pun begitu bersemangat dan menginginkan agar bentuk pengabdian seperti ini dapat dilakukan secara berkesinambungan.

\section{SIMPULAN}

Kegiatan pengabdian kepada masyarakat ini telah selesai dilakukan. Secara umum, seluruh kegiatan yang telah dilakukan mulai dari persiapan pengabdian, persiapan survei, penentuan masyarakat sasaran, penentuan lokasi kegiatan, pengurusan perizinan, penyusunan materi, pelaksanaan penyuluhan dan pelatihan, serta penyusunan laporan kegiatan dapat berlangsung dengan baik, lancar, dan sukses. Tim pelaksana pengabdian juga menyusun sebuah leaflet Kecamatan Cibalong sebagai produk dari hasil kegiatan pengabdian ini. Leaflet ini selanjutnya diserahkan kepada Kecamatan Cibalong untuk dijadikan salah satu media promosi dan informasi terkait pariwisata di Cibalong.

Dalam kegiatan pengabdian ini pemilihan metode penyuluhan dan metode praktik langsung berupa pelatihan menulis deskripsi asal-usul nama tempat (toponimi) dengan sasaran unsur aparat desa dan pemuda penggerak budaya, pariwisata, dan pendidikan di Kecamatan Cibalong, Kabupaten Garut dianggap tepat. Kegiatan penyuluhan dan praktik langsung dapat mendorong dan membangkitkan kesadaran masyarakat sasaran terhadap budaya lokal, dalam hal ini toponimi. Melalui kegiatan penyuluhan ini, masyarakat sasaran diharapkan dapat mengembangkan dan meningkatkan tempat wisata yang ada di Kecamatan Cibalong, Kabupaten Garut berdasarkan potensi yang ada di tempat tersebut. Dengan demikian, melalui program pengabdian kepada masyarakat ini diharapkan permasalahan yang selama ini mengemuka dapat mulai diatasi.

Perubahan sikap yang dialami oleh masyarakat sasaran setelah mengikuti kegiatan pelatihan ini antara lain: kesadaran masyarakat sasaran terhadap pentingnya menggali potensi budaya lokal semakin bertambah, pengetahuan dan wawasan masyarakat sasaran akan budaya terutama terkait toponimi dan cerita rakyat semakin luas, pengalaman masyarakat sasaran dalam praktik menulis deskripsi toponimi di media sosial merupakan butir penting dalam kegiatan. Selain merupakan pengalaman baru, kemampuan menulis deskripsi toponimi yang telah baik harus terus diasah dan ditingkatkan agar promosi daerah wisata Kecamatan Cibalong, terutama wisata pantai dapat terus meningkat.

\section{DAFTAR PUSTAKA}

Agustiningrum, T. E. \& Anisa, D.R. (2019). Peningkatan Sektor Pariwisata Kabupaten Sragen melalui Pengembangan Booklet Pariwisata Berbahasa Perancis. Dalam Jurnal Pengabdian kepada Masyarakat Universitas Negeri Semarang. ABDIMAS, 23, (2), 139-151.

Dian, I, \& K,G. (2018). “Upaya Membangun Jati Diri Siswa Sekolah Dasar Melalui Kajian Komparasi Dongeng Indonesia dan Jerman. Dharmakarya, 7, (4), 238-242.

Efendi, O.U. (1986). Dinamika Komunikasi. Bandung: Remadjakarya.

Oktavianti, R. \& Riris, L. (2017). Penggunaan Media Sosial Sesuai Nilai Luhur Budaya di Kalangan Siswa SMA. Indonesian Journal of Community Engagement UGM, 3, (1)

Pemerintahan Kecamatan Cibalong. (2019). Laporan Bulanan Kegiatan Pemerintahan, Pelaksanaan Pembangunan dan Pelayanan/Pembinaan Kemasyarakatan di Kecamatan Cibalong. Kecamatan Cibalong.

Samsudin, S. (1977). Dasar-Dasar Penyuluhan dan Modernisasi Pertanian. Bandung: Binacipta.

Sobarna, C. (2019). Toponimi dalam Upaya Pemertahanan Bahasa Sunda di Wilayah Jawa Tengah: Kasus di Kecamatan Dayeuhluhur, Kabupaten Cilacap. Jurnal Kajian, Komunikasi, Bahasa, dan Budaya Makna, 4, (1), 154-173.

Setiawan, R.E. (2016). Pengembangan Sumber Daya Manusia di Bidang Pariwisata: Perspektif Potensi Wisata Daerah Berkembang. PENATARAN, 1, (1), 23-35.

Wiseza, F.C. (2017). Faktor-Faktor yang Mendukung Pengembangan Objek Wisata Bukit Khayangan di Kota Sungai Penuh Provinsi Jambi. Nur El-Islam, 4, (1), 89-106. 